\title{
14 Challenges to preventing women abuse in rural communities
}

The purpose of this chapter is twofold. First, the chapter discusses the actions under way to address violence against women in Sweden, following the conclusions about violence against women presented in Chapter 10. To frame the Swedish case, this chapter briefly reviews some of the current international literature in criminology on actions countering violence against women. Particular focus is on the role of the community through crime prevention initiatives to tackle the problem in rural municipalities. Secondary data, email surveys, media excerpts, and face-to-face interviews are used to illustrate current initiatives to prevent violence against women in rural settings. The chapter concludes with examples of good practice in Swedish rural contexts and closing remarks.

\section{Addressing violence against women in an international perspective}

Providing help in a shelter may be the first step in establishing a safe environment for women victims of domestic violence but it is not the solution. Police and criminal justice interventions are crucial to stop violence against women, though they may result in the unintended consequences of more violence to both victims and offenders (Danis, 2003). A successful intervention may require the involvement of police, healthcare, judicial, and legal services, shelters and protection services, schools and other educational institutions, religious or cultural groups, and others. The United Nations for Gender Equality and the Empowerment of Women (UN, 2011) strongly recommends that to effectively combat violence against women, community support is needed.

Danis (2003) indicates that the coordinated community response strategy has had success by showing that a combination of legal interventions has better outcomes than the use of one strategy alone. If community plays an important part in prevention, the "local culture" has to be aligned in favor of gender equality and against women's abuse. In Chapter 10, we discussed how ignorance or neglect of violence against women is far too often part of the rural culture, in some cases allowing violence to escalate to a level at which women are killed. The police must be backed up with systematic knowledge to act in cases when repeated violence has already occurred. The community can play an important 
role in supporting women who need to leave relationships that are abusive. Resources at different levels have to be in place to make available women's shelters and enable criminal justice procedures that can protect a woman while she is starting a new life, away from an abusive partner.

Prevention of violence against women occurs in two ways: either by preventing repeated attacks (e.g., by tackling the abusive partner) or, in the long run, by changing values and social structures which promote violence. The majority of work worldwide has focused on attempting to reduce the incidence of repeat victimization by providing legal, welfare, and social support for women and, to a more limited extent, by attempting to control and change gender differences (Home Office, 1994).

An important body of research focuses on the UN-inspired coordinated community response programs which intend to establish support networks for victims and their families. How they work depends on each community's capacity to protect victims, hold perpetrators accountable, and reinforce the community's intolerance of violence against women. Becoming free from a partner's violence is not an easy process - whether by leaving an abusive partner or otherwise. Previous research recognizes that both social isolation and an effective community response contribute to a woman's increased risk of violence by partners and ex-partners (Aguirre, 1985; Sullivan \& Bybee, 1999).

In the United States, there have been three types of intervention against women's violence: intervention focused on men in batter-men's groups, on couples counseling, and on community intervention projects. Despite the growing use of both criminal justice and social service interventions, the evidence for their efficacy in the 1990s is not clearly established (Tolman \& Edleson, 1995). Tolman and Edleson suggest that although research contributed to an ongoing dialogue about how best to meet the challenges related to violence against women, there are as yet no conclusive findings about the best way to respond to male violence, and research rarely provides a clear-cut direction in policy and practice. More recently, Bennett and Williams (2001) report on the overall effectiveness of these programs, while others (Sullivan \& Gillum, 2001) refer specifically to the quality of advocacy for battered women in these frameworks.

In the United Kingdom, there is also a growing body of research on crimecentered approaches and mandatory policies toward domestic violence and how they affect women negatively (Coker, 2004; Mills, 1998). Stover (2005, p. 452) suggests that although recent studies have focused on beginning to evaluate domestic violence interventions and their effects, "there is still a great deal of work to be done to understand how to implement effective interventions to reduce domestic violence and improve outcomes." In the United Kingdom, the recent introduction of risk assessment and management processes in domestic violence cases has taken place at a time of concerted efforts by the British government to raise the profile of domestic violence and improve the response of all agencies, including the most significant overhaul of the law on domestic violence since the 1970s (Hoyle, 2008). 
However, studies that report experience combatting violence against women in rural settings are still the exception. In the United States, for instance, Benson (2009) reports the Illinois experience in dealing with domestic violence and concludes that police officers are not responding adequately to domestic violence situations, especially in rural areas. Concerning rural Australia, Bull (2007) highlights the limitations and challenges of providing services for women in rural areas, whilst Carrington (2007) associates violence in rural areas with a crisis in rural masculinity. Owen and Carrington (2014) examine domestic violence service provision in rural Australia and conclude rural service models are urbancentric and ignore the architecture of rural life.

One of the most recent examples is provided by DeKeseredy, Donnermeyer, and Schwartz (2009) in a discussion of how key principles of Crime Prevention Through Environmental Design (CPTED) can be applied to help design appropriate community-based prevention strategies to improve the security of women living in rural places from abuse by spouses and partners in both ongoing and terminated relationships. Beyond "modifying the built environment" to reduce crime opportunities in public places, as often postulated by first-generation CPTED studies, DeKeseredy et al. (2009), focus on communities' capacity and readiness (Donnermeyer, Plested, Edwards, Oetting, \& Littlethunder, 1997) to propose actions to prevent abuse of women in rural settings. Second-generation CPTED, as it is called, is about developing and improving forms of defensible space (in this case, perhaps the private sphere, too) through community-level activities that generate locally based discourse on norms, beliefs, and values related to various security issues which can serve to deter abusers. The authors suggest four overlapping strategies to combat violence against women and to improve their safety: community culture, connectivity and pro-feminist masculinity, community threshold, and social cohesion.

a Community culture. The development and reinforcement of local shared culture that makes people aware of gender-related violence and decreases their tolerance for domestic violence. Festivals, sporting events, music, and art enjoyed by the local community with the assistance of community members can be used for breaking down rural patriarchy and promoting greater awareness of women abuse by giving voice to the issue and confronting public expressions of rural patriarchy (DeKeseredy et al., 2009).

b Connectivity and pro-feminist masculinity. There is a need for initiatives that support women (e.g., easily accessible women's centers/shelters in rural communities) as well as interventions directed toward men, such as a profeminist men's movement, that argue for more action by men to stop women abuse and violence. These initiatives aim at changing in the long run the attitudes of men who are already violent toward women but also at encouraging others to break the silence when violence occurs or to avoid behaviors based on gender discrimination, such as boycotting strip clubs and confronting men who make sexist jokes.

c Community threshold. Fear among victims of violence isolates them, making it difficult for victims to develop social ties with neighbors who 
might be willing to confront a man who is violent and for victims to learn about services available to them. Community threshold can be enhanced and violence reduced in places where people come together for informal social control and act for the common good, such as activities against abusive behavior or supporting interventions that reduce women abuse.

d Social cohesion. Second-generation CPTED studies show that positive communication skills and conflict resolution enhance cohesiveness (Saville \& Clear, 2000). Thus, schools could be a natural arena for courses and information for all, young and old, in many rural communities.

We now turn to actions for victims of violence in rural Sweden, those provided by social welfare, police, and non-governmental organizations as well as the work organized around local crime prevention councils. As highlighted in Chapter 10, there has been an increase in reported cases of violence against women as well as the number of women searching for hospital care for domestic violence in rural Sweden. There are indications that this increase is not geographically homogeneous across the country and can be related to the levels and quality of the assistance provided in these communities. Appendix 14.1 lists the main sources of data used in the study.

\section{The Swedish national action plan against violence against women}

Sweden has a long tradition of gender equality policy. Early on, Sweden criminalized the purchase of prostitution services, enacted measures to combat sexual harassment in the workplace, and successively broadened definitions of sexual violence. Sweden constitutes an interesting case because the country has the highest figures of reported rape in Europe but one of the lowest conviction rates (Lovett \& Kelly, 2009). Sweden has a strong reputation for addressing violence against women, which partially explains its high rapereporting rates. These recent reforms were influenced by a tradition of gender equality policy and legislation, as well as an established women's movement, that culminated with the 1990s Kvinnofrid (protection of women) legislation and changes in the penal code after April 1, 2005. This introduced a holistic package of measures intended to address violence against women. These measures include crime definition, improvement of support to victims, knowledge building, and public debate about violence. Although it has been argued that these legal and other factors have maximized the reporting of violence against women in Sweden, it is an open question whether these changes alone are sufficient to explain the disparity in reporting rates within Sweden and between Sweden and other countries.

In practice, this urgency turned into the largest fiscal commitment to equality issues ever carried out in Sweden. The parliament approved SEK1.6 billion directed to gender equality, a tenfold increase in resources compared to previous years. Of these funds, around half a billion have been used to combat men's 
domestic violence against women. According to the national Swedish newspaper Dagens Nyheter, the government invested a total of nearly SEK1.1 billion from 2006 to 2012. Money has been used in a variety of actions (Figure 14.1).

Yet there is no indication that fewer women are subjected to violence. On average, 17 women are murdered at home each year. It is estimated that around 12,000 women are beaten in their homes by the person closest to them. In 2002, 1,571 cases of gross violations against women were registered by the police, while 2,513 cases were registered in 2011. Although this may suggest that little has been done to prevent violence, it can also paradoxically mean that now the means are in place that allow women to come forward and report violence. What goes against this positive assumption is the fact that although large sums have been invested in countermeasures since 2006, the number of cases seems not to be strongly affected by them. The National Council of Crime Prevention assessed the national action plan, stating that an "impressive amount" of activities have been carried out, "but the impact on target groups is more uncertain" BRA (2009). Rying (2012) highlights the central role of local actors/communities in preventing this type of crime.

I suggest a central authority in each municipality where women can turn to and get help from one and the same person, so that they do not have to run around. We constantly see cases of lethal violence against women that could have been avoided with better cooperation among authorities.

(Interview with Mikael Rying, 2012)

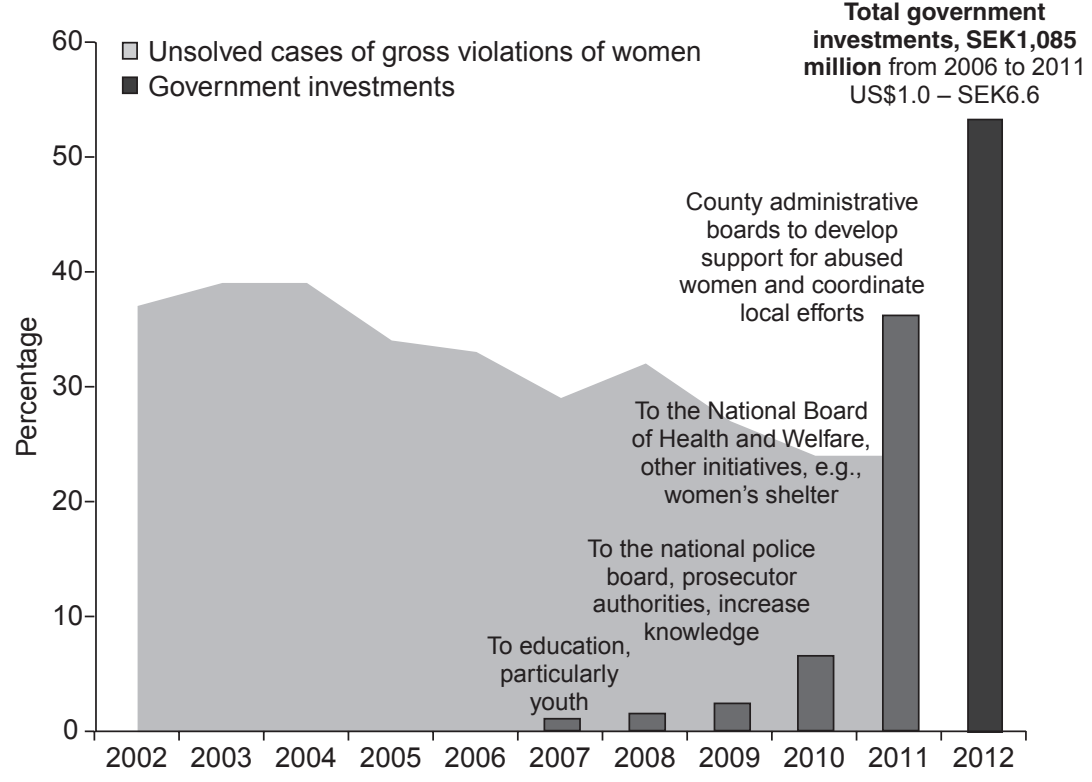

Figure 14.1 Unsolved cases of gross violations against women, 2002-2011, and government investments, 2006-2011, in Sweden (data source: National Council of Crime Prevention, published by Dagens Nyheter, see Beausang, 2012). 
A number of suggestions have been put forward, from more active and rapid action by the police and other criminal justice agents such as prosecutors, to improved and continuous knowledge-sharing by all actors involved at all levels.

\section{Women's shelters in Sweden}

For many women, leaving their partners is their last option, not because they do not want to but because they feel trapped and cannot see a way out of their abusive relationships. One problem is that people still think that battered women could simply leave if they wanted to. This assumption not only ignores many structural obstacles preventing women from leaving (e.g., geographical and social isolation) but also neglects the fact that many women really want to leave their abusive partners, at least temporarily, for a shelter. This section focuses on the urban-rural distribution of women's shelter in Sweden.

Support for women victims of domestic violence can be provided in Sweden by social welfare and related services, police, and non-governmental organizations in each municipality. According to the Swedish Association of Local Authorities and Regions (SKL, 2009), municipalities report particularly good experiences from collaboration among women's shelters, police, and municipal governments when dealing with violence against women. But it was not always like that. In 2001, more than 60 municipalities in Sweden (out of 290) gave no support to women's shelter organizations (NCK, 2001)

According to SKL's 2009 report, municipal support is now higher: at least 96 percent of those municipalities participating in the survey offer some sort of counseling in the acute phase of violence and at least 75 percent offer more longterm counseling. In the case of counseling for children and youth who have experienced violence in intimate relationships, at least 92 percent of the municipalities offer emergency support calls and at least 80 percent offer more longterm counseling. An absolute majority of the municipalities also offers risk assessment and support to police trial. Of the municipalities that responded to the survey, 89 percent said they offer protected accommodation for victims, and as many as 80 percent said there was a women's shelter in the municipality (Andréasson, Stenson, Björck, \& Heimer, 2006; Weinehall, 2005).

Internationally, shelters are the cornerstone of services offered to victims of domestic violence. These agencies typically offer crisis intervention services and may or may not provide immediate shelter, long-term counseling and support (Sullivan \& Gillum, 2001; Allen, Bybee, \& Sullivan, 2004).

The process of creation of women's shelter was similar in Norway, Denmark, and Sweden and shows similarities with the process in the United Kingdom, the United States, and Canada since the early 1970s. At that time, women's shelters were places with emergency phones and beds where women and children could seek shelter from a violent man. Nowadays, shelters are not regarded as institutions, but as a place where women can get help and support and meet women in similar situations. Healthcare, police, and social services are important partners but they cannot replace the shelter's crucial work. In Norway and Denmark, 
municipalities are responsible for financing these centers, though the state contributes. In Denmark, the state pays half of the municipality's expenditure. In Norway, the funding of these shelters is integrated into state block grants to local governments. Funding in Sweden is more complex. Some shelters are run by the municipality and financed by one or more municipalities, possibly with the addition of daily fees, while others are privately run with daily fees. A majority is run by non-profit organizations such as women's and girls' shelters. They are often financed by a combination of operating subsidies from the municipality, daily fees, and donations (Socialstyrelsen, 2013).

In the Swedish case, the Swedish Association of Women's Shelters and Young Women's Empowerment Centers (SKR) is a national organization for local women's shelters and other organizations that work primarily against men's violence toward women. The shelters were started by volunteers, always women. Today, they are run by volunteers, sometimes together with paid employees, and there are shelters for about 190 of Sweden's 290 municipalities; some of the major municipalities have several shelters. They are organized in two national associations: the National Organization for Women's Shelters and Young Women's Shelters (ROKS), which organizes 126 shelters, and SKR, which has 32 member organizations. Women may seek a shelter for several reasons. The most common is that they need to talk to someone who understands the problem of domestic violence. Quite often women flee to shelters to escape a man's violence, often in dramatic circumstances. These women may be offered shelter and sometimes protection. Many of them bring children with them (NCK, 2001).

The President of ROKS has worked with abused women for more than 30 years. Beausang (2012) is rather pessimistic about what still lies ahead:

Many programs have come and gone, we've had new legislation and awareness of this type of crime has increased but the violence has not decreased.... Police and prosecutors must learn the special problems of these crimes... The problem is that there is a lack of continuity of knowledge.

Women's shelter organizations are often concentrated in urban municipalities, often large cities, and vary in terms of the services they offer (Figure 14.2). What is worse is that most rural municipalities have none. According to SKR's database, only three out of 22 remote rural municipalities in Sweden have any record of having women's aid organizations (rate of 0.14). They are located in northern Sweden and are geographically large municipalities: Storuman, Överkalix, and Pajala. In accessible rural municipalities, a bit more than one-third of them have records of having at least one organization of this kind (rate of 0.43). Half of the municipalities regarded as urban have at least one women's shelter and/or organization that supports victims of domestic violence (rate of 1.09). Some urban areas have none, while others have more than two, such as Stockholm, Gothenburg, Malmö, Lidköping, Skövde, and Eksjö. Whilst the great majority of women's shelters and supporting organizations are registered in SKR's database, a small number of independent shelters are not recorded in the national database. 

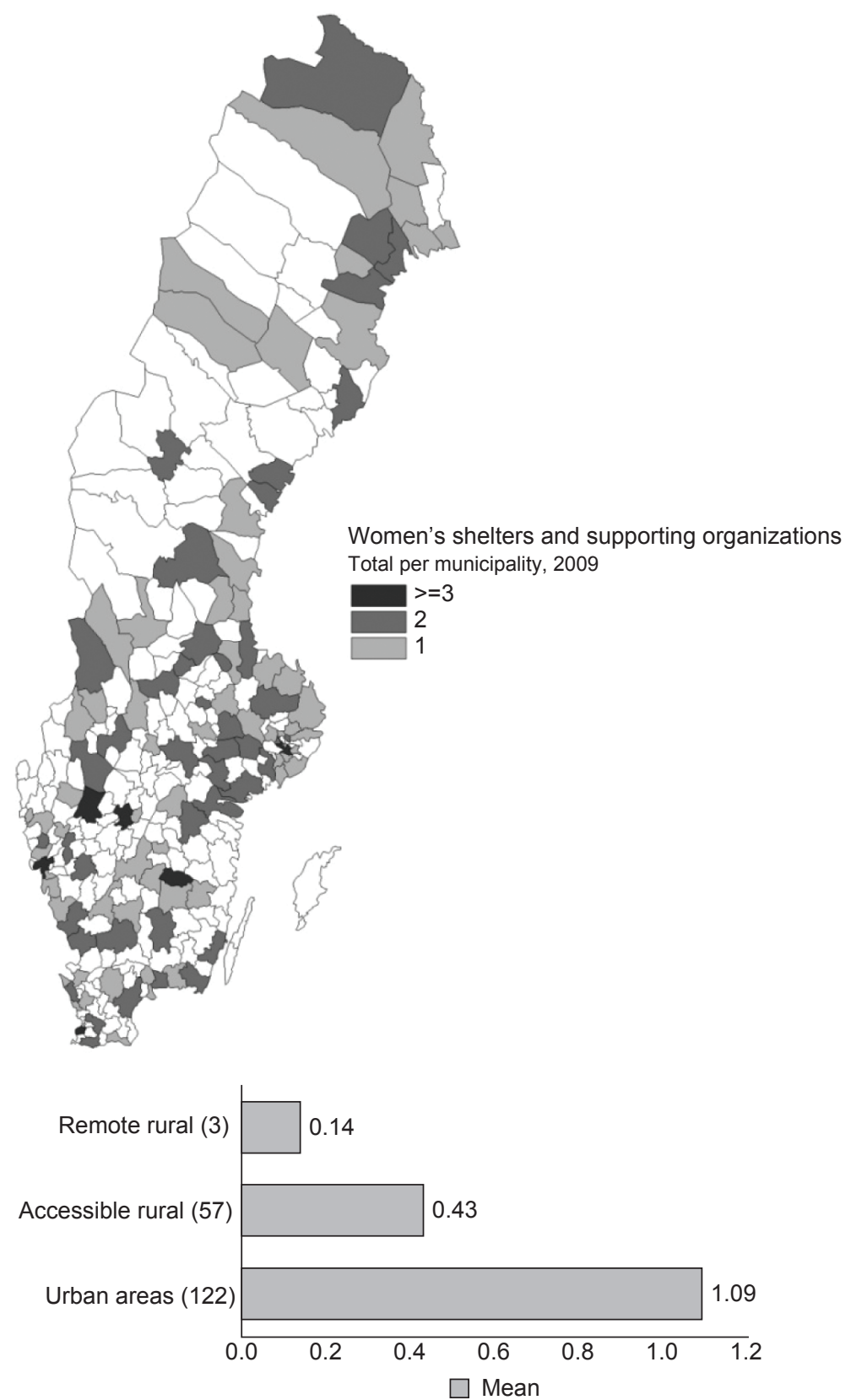

Figure 14.2 Geographical distribution of women's shelters by Swedish municipalities and rates, by municipality by type (data source: SKR, 2009).

Note

The remote rural municipalities with a women's shelter are Överkalix, Storuman, and Pajala. 


\section{Sweden: policing and crime prevention}

Since the mid-1990s, the Victim Support Association has also developed activities with a special focus on violence against women often (but not only) after the victim has been to the police. The Association currently consists of approximately 100 local Victim Support units that cover all the country's police districts. Victim Support is a non-profit association, independent of religious and political affiliations. Their task is to support and help victims. Regardless of where one resides in the country, support is provided by Kvinnofridlinjen, which is a national helpline set up in 2007 in multiple languages for those who have been subjected to threats, violence, or sexual assault. They are open around the clock, and calls to them are free of charge and do not appear on the caller's phone bill. All these services characterize the kind of support that can be found in Sweden.

In the next section, we discuss the role of local crime prevention councils (and other related groupings) in relation to violence against women in Swedish rural areas.

\section{Local partnerships against violence against women}

In Sweden, the implementation of community safety schemes based on local partnerships (crime prevention groups, or CPs) went hand-in-hand with overall decentralization of the police in the mid-1990s. Violence against women was put on the agenda of these partnerships in the mid-2000s often involving social welfare and healthcare, police, and organizations supporting women. This development has been pushed forward since the creation in 1994 of the national women's center (Rikskvinnocentrum). In 2006, this was augmented by the national knowledge center (Nationellt Kunskapscentrum, or NKC) on violence against women. Equally important since the 1970s has been the women's movement, through support groups that work with victims of violence against women, such as ROKS. Important in this development was also the Kvinnofrid (protection of women) legislation implemented in 1998, which turned repeated violence against women into an offense in its own right. So far, the role of individual actors in dealing with cases of violence against women has been assessed separately, such as the role of healthcare (Andréasson et al., 2006), municipalities, and police (Weinehall, 2011). These assessments rarely look at the role of local crime prevention partnerships as a whole at the municipal level.

To assess the actions of these groups against violence against women, data from three different sources were analyzed: semi-structured interviews with representatives of CP groups in eight rural municipalities, analysis of SKR database, and responses from an email survey to all representatives of CPs. The email survey helped to select the eight case-study municipalities that were further investigated using face-to-face interviews, as discussed in the next few pages. Semi-structured interviews were conducted face-to-face (in Swedish) with members of local CP councils in eight selected municipalities. The questions were adapted to accommodate the difference in expertise of each $\mathrm{CP}$ 
member. A minimum of five and a maximum of seven people were interviewed in each municipality (49 interviews in total; about six individuals per study area). These people included policy officers, school representatives, representatives of women's shelters, county council representatives, social services, other NGO representatives, and citizens.

In addition, a short email survey was based on hypothetical scenarios and sent to all municipalities with a CP group in rural Sweden. The response rate was 62 percent. CP members were invited to describe the most important short- and longterm actions they would take as a group to deal with the following scenario.

Domestic violence is a problem in your community. Some residents have lately heard of violent events in one particular family. The woman shows signs of having been exposed to violence (bruises and other physical marks) but has not reported these to the authorities. Neighbors and residents nearby would rather not "interfere" or they think that they prefer to concentrate on their own family business. Some people think that domestic violence is not something to worry about. If such a matter is brought to your attention, what would the local crime prevention council do to tackle this problem and to prevent similar problems occurring again in the future?

According to the survey and interviews, domestic violence is a question that requires coordinated actions among different local actors. Good coordination and sharing knowledge are often highlighted as important ingredients to tackling violence in the private sphere and were the most common action $\mathrm{CP}$ members stated they would take.

Strikingly, domestic violence was not considered part of the "daily" agenda in one-quarter of the local crime prevention groups that answered the email survey. (They either stated it clearly or did not answer the question.) Most of the groups see themselves as "a coordinating organ" which has a comprehensive view of what can be done to support the victim in the short and long run.

Social services (first) or other members of municipal social boards or experts are regarded, in 85 percent of the cases, as important actors to deal with domestic violence (Figure 14.3a). Commonly, those who are active members of crime prevention groups are themselves responsible for these specific tasks in the municipalities. They would probably make home visits, report the events and begin an investigation. They also highlight the need to create a secure relationship with the woman in question and, in some cases, offer the possibility of establishing an immediate contact with the women's shelter. The clear links between women's shelters in this process seem to be fundamental for half of the respondents. If beatings occur, they have to be reported, so bruises and other injuries can be documented by a doctor and healthcare center and the case can be reported to the police. Many argue that different actors and authorities cooperating in cases of violence prevent the situations from "falling between the cracks" in the system. 


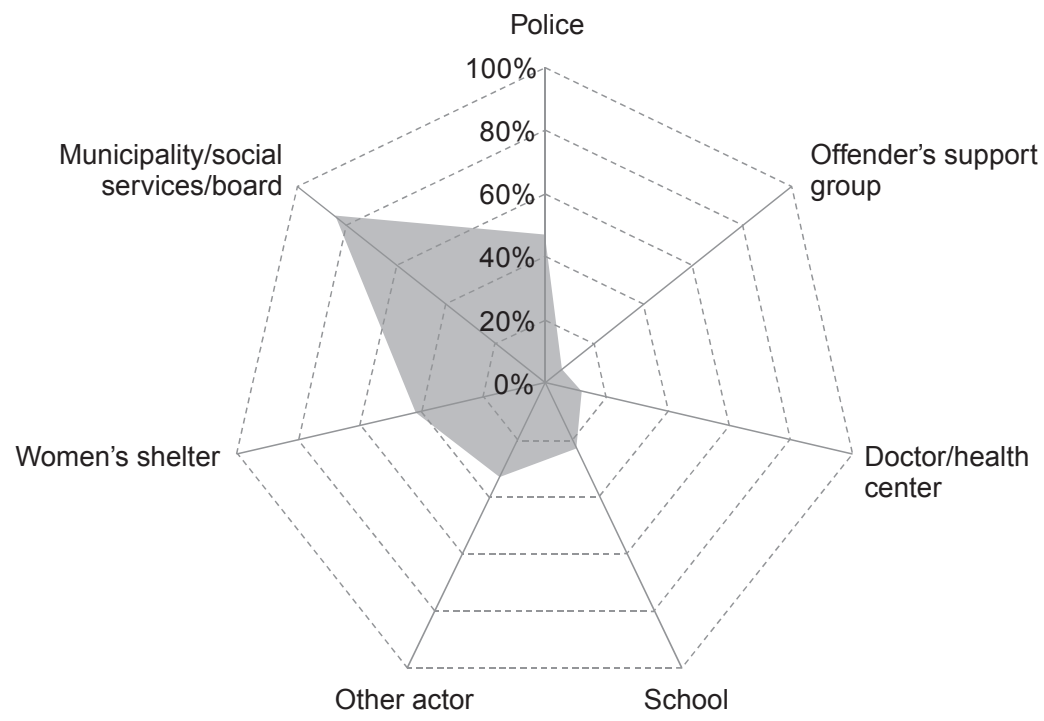

(a)

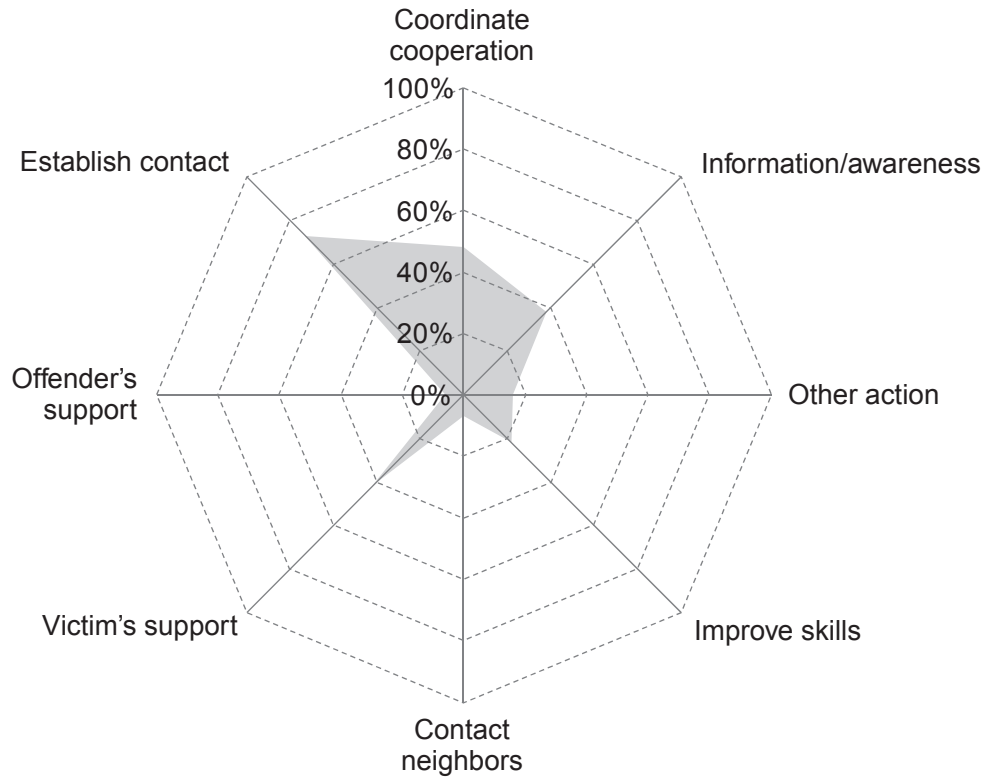

(b)

Figure 14.3 (a) Who should address domestic violence? (b) How would CP groups address domestic violence? (source: own survey, $N=60$ local crime prevention councils). 
Although a majority of respondents declare that the role of crime prevention councils in cases of domestic violence is only to coordinate, they still show signs of having a clear strategy on how they would tackle the problem if it appeared in their community (Figure 14.3b). Two-thirds of crime prevention groups would establish contact with the relevant local authorities in an institutionalized way, using channels of support that already exist for victims. Improving the existing networks linking local actors is also regarded as important. In the long term, improvements in personal skills for handling violence and providing information are also considered relevant. Support for both victims and perpetrators is regarded as a must in some municipalities. Unexpectedly, very few declare that they would rely on strategies based on informal social control of neighbors and friends of victims.

Half of the respondents think that domestic violence has to be brought to the attention of police (the others declare that it is the woman's right to decide whether she registers the crime) and in nearly all cases the relationship between victims, local community, and authorities is regarded as unproblematic. As suggested by DeKeseredy, Schwartz, and Alvi (2008), strong social control, common in rural areas, might inhibit women from reporting events or even prompt them to hide such events from neighbors or local authorities, particularly the police. However, one of the respondents reflected upon the current barriers a woman may face when victimized and what is needed to improve the current conditions:

Helplines can get them to dare to report. There may be reasons why many do not dare to report ... I guess they do not want to end up as a little item in the newspaper ... or they don't want to go to hospital (large women's workplace) because they don't want to show their injuries. The municipality must have a plan to support everyone involved ... perpetrator, victim, children and others. A joint plan with the police, prosecutors, healthcare and others.

(A respondent from southern Sweden)

Many representatives highlight the need for a long-term strategy to support victims, particularly for social services to assist in making a plan for what the family needs and may be willing to receive, possibly supporting the woman in a separation. The role of the school in this process was highlighted in two ways: first, by supporting the children as they might be witnessing these violent events at home; second, by educating and improving gender awareness for school-aged children as a preventive measure. Some respondents highlighted the importance of providing education to those who can actively intervene if violence breaks out at home, such as the caretaker in a housing association.

\section{Emphasizing the role of the police in prevention}

Although the Public Prosecution Office in Sweden has invested heavily in fighting violence against women, the number of reports of violence and threats 
against women has increased while charges have decreased. Some prosecutors believe the problem lies with the police:

I feel that the judicial police training should be improved. The police would be better at interrogation and treatment. There's a shortage of trained police that can quickly get into the problem.

(A prosecutor in the Stockholm region, in Stengård, 2009)

Recent discussion in the media about women's homicides indicated the role of the police is fundamental in preventing women abuse in rural areas. Jönsson (2013), from the police in Västernorrland, whose team analyzed dozens of cases of homicide in the past 12 years in an area of southern Sweden, says in a radio interview that she believes the police should play a more important role in combating violence against women. Jönsson suggests that, to improve the prevention of violence and killings in close relationships, the police must work more systematically. There is a need to create a database of addresses where there have been repeated calls of fights and/or domestic violence. Such information could provide patrols with more knowledge about what to expect from a particular case in what Jönsson calls "flat fights." She points out that this is particularly crucial at critical stages of victims' lives, such as when women want to separate from their partners or husbands or leave their parents' homes against their will:

Had we taken these more proactive actions, using skills that are actually in place, we could have certainly prevented a number of murders.

(Jönsson, 2013)

In addition to gathering evidence, there is also a need to ensure that battered women do not withdraw complaints or notifications made to the police, especially in situations in which the separation process is under way and when quarrels are more frequent. Another proposal entails the creation of counseling support for those who have a past of violence and are in the process of separation, to avoid situations that can escalate into violence and murder. Another important component of prevention is the way a restraining order is put into practice by criminal justice. A restraining order (prohibition of contact between a perpetrator and the victim) is said to be insufficient. In the future, a restraining order should be combined with electronic surveillance, with electronic differential tagging on the perpetrator at the same time that the restraining order comes into force. Long-term intervention which does not necessarily involve the police also ought to be put in place to support women to dare to leave a destructive relationship, avoid violence, and, in the worst case, to avoid being murdered. This means that women must get more help than is currently the norm in Sweden, as in some cases they need help finding a new home, a school for their children, and maybe even a new job - all these places far from the abuser. 


\section{Unlocking women's violence in the rural context}

I: What about men's violence against women? Is this something you see a problem with?

R: No, not really. We discussed it at the previous meeting when $\mathrm{X}$ brought the statistics ... there was no case. It is one thing here and another assault case there, but domestic violence or violence against children, or rape.... We are pretty spared from it actually. Luckily. Why? I don't know if women don't dare to report it or if the "free church belt" makes you have a different view of it.

Although not specific to Sweden, the case above illustrates one of the most important challenges in tackling violence against women in rural areas: to get evidence that violence is actually taking place. Can violence against women be truly addressed if there is a "cultural blindness" that does not recognize the problem?

Answers from interviews show signs that domestic violence goes underreported in some of these municipalities. Although there seems to be a tight network between social and health services, police, and women's shelters, cases reported to the police are termed "low" in certain parts of Sweden. As pointed out in Chapter 10, differences in reporting rates of domestic violence may reflect differences in "gender contracts or regimes" (Amcoff, 2001; Townsend, 1991) that creates different conditions for both women and men. In places where more modern gender contracts dominate, there is "the right background" for women to feel accepted even if they report violent actions by their partners. In more traditional gender contracts, however, domestic violence may go undetected for different reasons. On the other hand, high levels of domestic violence in larger cities in the country might be a result of the supply of services, particularly police units, specialized in family conflicts to detect and register family violence.

When a victim actually reaches a women's shelter, she may not want to report to the police or social services. Some believe that the only way to change women's attitudes toward their partners is to invest in awareness and information through lectures in the community. Since it is a small community, information often passes mouth-to-mouth, which is sometimes more effective than the lecture itself. Others think that it is easier to approach abused women when there are children involved, since these women may have a larger interface with the local community and services than others who do not have children. Trust must be established, otherwise women do not dare to tell.

What we have seen in the women's shelter is that women would not report to the police or social services. Many times they come and talk about "friends" who have problems, and when they come a few times, then it turns out that their friends are actually them. We get it at once but we wait until they can tell their own story themselves.

(Women's shelter representative, northern municipality) 
After reporting an incident, a woman may still refuse to participate in the investigation, which is perceived by the criminal justice system as a problem. There are many different explanations for this. Women avoid reporting the case because of social and economic dependence on the perpetrator. Other explanations are that a woman's primary goal is to get out of the abusive relationship and not put the abuser in jail or that she was ill-treated by police or not believed (Weinehall, 2006). Despite being an exception, one respondent mentioned that women are guaranteed the possibility to choose their own contact person at the police, so they do not need to disclose themselves to more than one person after the first incident has been registered.

\section{Identifying "sectoral blindness"}

Crime prevention is rarely defined from a gendered violence perspective by those who work directly with violence against women in crime prevention partnerships. Our analysis shows that when local crime prevention partnerships deal with women's safety, the common agenda is to deal with fear of crime in public spaces (using safety audits or safety walks), not with violence that happens in the private sphere.

Although those living in rural areas feel safer in public places in their neighborhoods than those living in urban areas (BRÅ, 2008), interventions against aggression toward women in rural areas still focus on perceived safety in public places. Thus, as in urban areas, in rural areas the actions of crime prevention groups often tend to be guided by the dichotomy of discourse between private versus public spaces, neglecting the problem of domestic violence and giving priority to (fear of) violence in public places. Moreover, the priorities of crime prevention groups are often the result of an interplay of the interests of representatives in the local community in which the police still play an important role, which often results in less focus on violence by partners or family in the private sphere.

Of course, safety in public places is very important as it deals with a woman's right to move about safely in society. Decades of research have shown that the fear of being victimized by a crime is more prominent among women than men, but crime is just one factor that affects women's perceived safety (Ferraro, 1995; Lagrange \& Ferraro, 1989). Other types of behavior - such as intimidation, groping, sexual comments, harassment, and threats - also affect women's mobility. According to Loukaitou-Sideris (2014), fear leads women to utilize precautionary measures and strategies that affect their travel patterns. Whether traveling by bus, automobile, or other mode, women's fear of public transportation facilities (e.g., parking structures, buses, train carriages) affects the way they engage in travel and may preclude them from a basic right: the ability to move undisturbed from origin to destination without worrying that a "wrong choice" of mode, transit setting, or time of travel might have consequences for their safety. Women living in rural areas, particularly in countries with long travel distances like Sweden and Australia, may be extra dependent on private vehicles and public transportation to allow individuals to go to work or ask for help if 
anything goes wrong. For instance, a study of teenagers' movements in the suburbs of a middle-sized Swedish city reported a fear of traveling or of being alone in transit environments late in the evening (Aretun, 2009). Our case studies in Sweden show that violence against women is dealt with separately from other issues of outdoor safety and rarely relates to women's mobility. The dichotomy of actions between private versus public spaces is more often found among those crime prevention actions in southern municipalities than in the northern study areas, where alcohol and drug consumption and addiction are targeted by joint efforts against violence.

Although those who deal with violence against women may work separately from traditional activities in crime prevention, they do show signs of cooperation with neighboring municipalities both in southern and northern study areas on some gender issues. The type of support may vary. For instance, all studied municipalities are aware of and work to implement the regulations in the legislation to protect women (Kvinnofridslagen). The work done by the selected municipalities in the south and north of Sweden may be similar but, in terms of organization, they are different. In the north, the groups have a looser organization and work based on their individual responsibilities (e.g., the Linnea group is devoted to gender violence), whilst in southern municipalities the groups have a formal crime prevention alliance.

Although nearly all respondents describe their activities as being prescribed either at the national or regional level, there are indications they have some room to affect what happens locally. For instance, a group in southern Sweden decided, parallel to their current support to women victims of violence, to start a men's forum.

We have established a men's forum. It is a preventive effort aimed at violent men. They must first be able to contact us.... It is an outlet for their aggression before they hit their partner or wife. It is difficult to measure its success. They come to a special apartment that we have set up and then there is the opportunity to meet them anonymously.

(Coordinator, southern municipality)

Changes in priorities have now put the focus on domestic violence with more comprehensive involvement of multiple actors, but it seems that actions are taken without knowing how big the problem is at the local level. These groups' actions and the type of help they provide have become more institutionalized over the years, often following a top-down approach, from regional to local levels. Interestingly, there was not a single case in which any real records of domestic violence were declared as the basis for starting their activities.

I: But why did you start the project?

R: New law, the law changed.

I: So it was not as if you started the project because some statistics (on violence) increased? 
$\mathrm{R}$ : I'm no feminist as such, but no, there is nothing that we have seen here but you know that there is [violence].

(Project leader, northern municipality)

It is unclear why local actors do not track cases of violence against women if they "know" that they exist. If police statistics may fail to capture "the real numbers," health statistics (number of admissions/hospitalization) should reveal how serious the situation is. The same could be argued for women's shelters and local social services. Violence may extend to children, which could also be identified as a problem at school or day care.

\section{Tackling specific rural challenges}

Reaching all those in need and locating them are often regarded as difficult tasks in small municipalities. Some of these rural areas have women from ethnic minorities, from Thailand for instance, often brought to Sweden through marital ties or "marriage arrangements." Westman (2010) shows examples of how migrant women in rural areas exploit their positions and try to challenge the traditional norms in the Swedish countryside. Overall, for those who work with gendered violence, the challenge is greater when victims belong to ethnic minorities who may not speak the language or do not want to seek help for fear of being expelled from the country.

We have a lot of migrant women in the villages.... It is not easy. You need to reach everyone. We have women with addiction problems who are abused, we have women that we do not reach, who do not know the language. We have to get out the information that we exist.

(Project leader, northern municipality)

While it is important to note that abused women with a foreign background are a heterogeneous group with different social backgrounds, they may share a number of vulnerabilities: lack of knowledge of their rights, heavy dependence on the perpetrator, and limited social networks. Studies show that abused women with a foreign background often get incorrect information from the perpetrator. Threats such as that she would be deported if she left him or that her children would be taken away from her were common. Ethnic discrimination is another factor that can make foreign women especially vulnerable. When this happens there is a risk that the woman will be seen primarily as a representative of a culture and secondarily as an individual (Socialstyrelsen, 2014).

The women may also need emotional support and help to process events and find a way forward. Women who are not accustomed to living independently or who are new to the country may need help with practical tasks when they have left their partner and must create a life on their own. Good and competent treatment is a prerequisite for a violence-prone woman to receive community support and help. If the woman has limited language skills and limited knowledge of Swedish society the process can be even more difficult. 
More often in the north than in the south, Swedish respondents report the difficulty of dealing with domestic violence and addiction (especially alcohol addiction, sometimes by both victim and abuser) (Weinehall, 2011). The police highlight that some problems are "chronic" in rural communities and, although they follow routines, they lack total commitment when they are called several times to the same address (Weinehall, 2011).

There are also problems associated with long distances to services and support. As in many other rural areas (see e.g., Pruitt, 2008), local governments in rural places often struggle financially to maintain basic public services and resources. Respondents also indicate their own lack of skills and the group's poor resources for tackling violence in the private sphere. They travel to neighboring municipalities to attend courses and establish collaborative work. Cooperation between municipalities is an essential part of their work, especially in attempts to protect victims' privacy and anonymity. However, long distances may play a positive role in the process of looking for support. Anonymity can be safeguarded by "sending women to the neighboring municipality" where better resources can be found.

We found out that it is impossible to have women's shelters in small municipalities ... because everybody knows everybody.... So you have to cooperate. When we have no money to hire someone, we must find ways within existing resources. It is not easy. We must help each other. That is why we will work together with $\mathrm{X}, \mathrm{Y}$ and $\mathrm{W}$ municipalities. When something happens, it's primarily to $\mathrm{X}$ municipality that we sent women.

(Project leader, northern municipality)

Some are more active than others in working on issues to prevent long-term domestic violence. Information and education of young people, and of parents, is part of the agenda in nearly all study areas in northern Sweden. These lectures are often financed with joint support from the municipality, county council, and NGOs and encompass a range of issues, from drug and alcohol addiction (which is a problem particularly in northern municipalities), to changes in attitudes to traditional gender roles.

We had a play about boys' violence against young girls... We will also go up to T-municipality and H-municipality to hold lectures for parents of young people's habits on the Internet, because parents have no idea what the young people are busy with online.

(Safety coordinator, northern municipality)

An interviewee also mentioned that they found a course at the closest university on men's violence against women and children. They applied for money from the County Council so the police, women's shelter representatives and the municipality had the opportunity to take the course. In summary, there have been a number of initiatives from local crime prevention representatives to improve and spread new knowledge about gendered violence and its prevention. 


\section{Sweden: policing and crime prevention}

\section{Avoiding "acting in the dark"}

Those who work with issues related to violence against women face a number of other challenges in Swedish rural areas. Although local crime prevention councils show examples of good practice in a number of areas (Ceccato \& Dolmén, 2013), there is an overall lack of knowledge about "what works" and "what does not" in countering violence against women. However, this is not a problem exclusively of those who deal with domestic violence. The examples provided by those who participated in the survey show that the majority of the activities and projects conducted within a CP framework rarely reach the point of being assessed. Most of the "success stories" are often told in the form of anecdotes about people's struggles with poor resources to deal with gendered violence, the structural barriers they face, and how their work has made changes in the victims' lives (e.g., by providing shelter or making it possible for women to leave their abusive partners).

Many of those who were interviewed would also argue that being in a "small community" is an advantage for the type of work they do. They claim that any "problem" may be solved quickly because "unofficial talks" may become "official" just because people know each other. However, not everybody agrees. What is perceived to be an advantage by some may be an indication by others of unbalanced power relations. In cases where women abuse occurs, this may lead to what was termed by Barclay, Donnermeyer, and Jobes (2004) the "dark side" of gemeinschaft: violence against women is tolerated and conflicts are resolved "within the group."

\section{Aligning national goals to regional programs and local actions}

The great majority of respondents expect more resources to become available for long-term action, funding that can be earmarked at the national and regional levels for local action at the community level. They suggest that they need extra resources not only for their current activities but also for new ones (e.g., a girls' forum in a northern municipality, pro-feminist men's movement, such as a males' forum in the south). Better guidelines and knowledge of how to work together with other local actors to tackle violence against women is also desirable.

More knowledge could perhaps explain large regional differences in the number of domestic violence cases that go to trial. In some northern counties, only 20 percent of complaints of women abuse were prosecuted in 2012, whilst in counties with the best clearing percentages, Gotland and Jämtland, the figure was 69 percent (Beausang, 2012). In addition, the whole criminal justice system must be adapted to quick response in extreme cases of women's abuse. Restraining orders should be implemented more often, together with electronic tagging in extreme cases. Relocation of the woman to another community can be an alternative, but it requires resources and the coordinated actions of different actors. As suggested by Jönsson (2013) in a radio interview, actions like these may keep women from dying at the hands of violent partners. 
Some claim there is a mismatch between national and local policy, and also poor support for putting national guidelines on violence against women into practice locally. Some in the north also argue that "things decided in Stockholm do not take into account the conditions and resources of remote rural municipalities." The effect of this disconnect between national and local scales in policy has already been pointed out elsewhere by Pruitt (2008, p. 413). Referring to North American conditions, Pruitt argues that

challenges associated with domestic abuse are unlikely to be solved by action at any one scale. They also are not likely to be addressed effectively with national policies that ignore space- and place-based differences. Nor are they likely to be resolved entirely at the local level, particularly in light of the lack of resources.

This calls for responses that represent collaboration between national and regional levels on the one hand, and local on the other.

\section{Two examples of good practices}

These two examples were selected because they are interventions that combine individual and community-based actions. These initiatives intend to establish networks of support for victims, offenders, and their families, which has been an important goal in the UN-inspired coordinated community response to gender violence.

Moreover, the selection of cases is limited by the views, experiences, and perceptions of those who work with crime prevention in eight rural municipalities in Sweden. Although they may reflect a rich variety of rural municipalities in the country, conclusions cannot be generalized for all rural areas, with similar types of initiatives. Despite these limitations, we believe it is important to be able to report on the experiences of those working with women's abuse in these two examples. In the future, it is important to focus on the views of those who seek support either as victims or perpetrators of violence.

\section{Women's shelter in Storuman}

The women's shelter called "Kvinnojouren i Storuman" started in 2004 by local nurses who had experienced many cases of abuse against women. They took the idea to a member of the community council, who was later backed up by social services, and then the group was formed. Since then, they have had a good response from the authorities and society at large. When they started their activities, neighboring municipalities (e.g., Sorsele) wanted to get involved. Nowadays they share the apartment and running costs. They now have seven people who work on a number of cases. Some of the work is done at the individual level. 
R: Yes, the problem is psychological abuse, you know, to access it, and reduce it. It is a preventive program that you do not know how long it can last.

I: How do you work with it?

R: By boosting women's self-esteem and gaining confidence. It is extremely important; it is what is lacking in them. They must be aware that they have self-worth. It is so easy to become depressed. If you are confident in yourself, you dare to go against [your oppressor]. One should not simply put up with crap.

Activities run by the women's shelter organization in Storuman also represent good examples of a community-based approach toward prevention of gender violence. The group attempts to develop and reinforce a shared long-term culture that does not tolerate women abuse and constantly tries to prevent it through training and information. As Saville and Clear (2000) indicate, positive communication skills and conflict resolution enhance cohesiveness. Thus, schools and local community centers can be used to provide information and training in rural communities. One of the members of the group gives examples of how they work in a preventive way together with the community:

On March 8, the women's shelter usually sponsors free bowling and coffee for women and girls, and this year, the girls invited boys. We had 100-110 people there. It was amazing for such a "little Storuman." Out in the schools, we must do this. We have to reach out to young people.

(Women's shelter)

In Storuman, they are constantly searching for resources, to invite people for lectures on the theme "gender and violence." At the time of the interview, they had applied for funding from the County Council and received enough to hold a number of lectures and training courses for people in the community but also for inhabitants of neighboring municipalities.

However, such preventive work faces challenges. Although various forms of violence against women share a number of commonalities, there is a common belief among women working at the women's shelter that the effective long-term prevention of the problem demands a better understanding of women's needs and their cultural contexts (Ingesson, 2012). A group that is relevant in northern Sweden is the Sami. The leader of the women's shelter, who has been active more than 20 years, says that in her experience the Sami society is patriarchal, consisting of a male-dominated power structure and individual relationships, with a systematic bias against women. Even within the Sami group, there is friction on values related to gender roles, such as between those who take care of reindeer and other Sami groups. As part of their work with prevention, the women's shelter in Storuman received funding from the County Council for interviews to assess Sami women's needs and life situations. Working against this progressive background is the local culture, which reminds us of its patriarchal values in the middle of the town (Figure 14.4). 


\section{Men's forum and women's safety walks in Gotland}

Gotland has one of the highest rates of clearing of domestic violence cases that go to trial (69 percent) in Sweden (Stengård, 2009). In Gotland they implement the ideals of a pro-feminist men's movement as described by DeKeseredy et al. (2009). The Men's Forum (Mansforum) was started in 2007 by men working with family therapy for social services (municipal) and with no connection to the various women's supporting groups that also exist in the municipality under the action program called Kvinnofrid på Gotland (legislated protection of women on Gotland). The Men's Forum was initially intended to be a place for men to talk, including those who had a history of domestic violence (men convicted of crimes). The Men's Forum also has a helpline. Eriksson (2011, pp. 24-25) reports on local initiatives against violence against women.

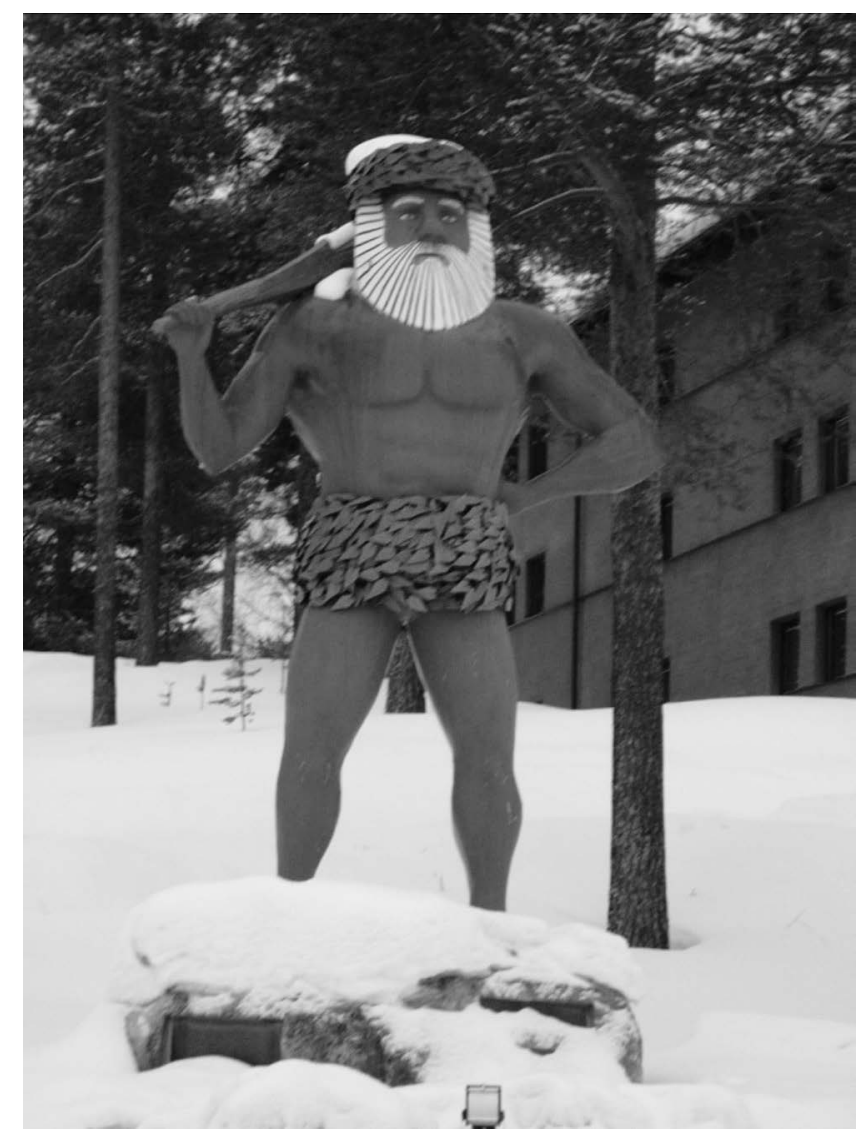

Figure 14.4 "The wilderness man": an ideal of masculinity or a symbol of patriarchal society? Storuman, Lappland, Sweden (photograph source: Carin Lånersjö, 2011). 
Most men who come to a meeting at Men's forum want more than just talk on the phone.... Those who are violent often come back several times as they feel they have difficulty controlling their anger and know that they scare people with it.

However, the initiative is not free from challenges. Since Men's Forum is not a completely formal activity within social services, it is always uncertain from year to year whether the forum will continue because of limited funding.

Another challenge is the lack of male personnel working in social services. As pointed out by Eriksson (2011), 25 women and one man are employed in family care services. Those men who come to the forum may agree with the participant at Men's Forum who said, "It's only girls there and they don't understand us." Almost all departments in social services are dominated by women. As in many other rural communities, attracting qualified personnel is a challenge, and often other priorities go before gender equality when new staff is hired for municipal services.

Since 2013, the group is functioning with three persons. They are part of the family support unit. Nowadays they devote about three hours a week to the Forum within normal working hours. That includes email contact, phone messages, and booking times for meetings (once a week). Persons referred to the Forum are obliged to come. They are usually men who have problems managing their anger. Others, who come on their own, are often men who got trapped living with a mentally ill partner, have a custody battle going on, or feel steamrollered by officers at social services and need someone to whom they can vent their problems.

All calls so far have been individual. The group's representative suggests that their challenge in the future is to initiate discussion groups. The municipality is a small place - everybody knows everybody - and there is a resistance among individuals to open up and talk about their problems with violence to a group, as chances are that others in the group know the person, their partner, or a family member.

There are also initiatives directed at women's safety in public places. A "safety walk" (or "safety audit") is an inventory of the features of an area (or a park) that affect individuals' perceptions of safety. Safety walks were introduced on Gotland in the beginning of 2009 with the objective of identifying physical environments that are perceived as frightening for women. They are also a way to engage and empower local women. Safety walks have initially been used to demonstrate how daily fears translate into concerns about the physical environment, which is useful information for planners (WACAV, 1995, p. 1). Safety walks have led to changes in the physical environment. At the time of the interviews, new safety walks were planned to tackle the problem of safety in the center of the city. Housing companies improved surveillance conditions (installed new lights, replaced broken ones, trimmed bushes), but interviewees believed that changes depended greatly on budgets. Bicycle sheds and park areas will also get extra lighting in the near future. 
Sandberg $(2010$, p. 21$)$ reports examples that these changes were not free of controversy, including comments by the person responsible for the outdoor environment in the inspected residential areas.

They have cleared a dense forest which was located in the middle of the block ... the measure was met with resistance. Almost 100 per cent of the disaffected were men who made their voices heard ... but many women came forward with encouraging comments about the changes.

(City Garden on Engineering Management, Gotland)

In Gotland, the public has been invited through advertisements on the municipality's website, newsletters distributed by the housing companies (distributed to all residents in the area), and information posted on notice boards in the areas to be inspected. Local community actors also took part: police, social services, leaders of local associations. According to the interviewees, the response from the public varied by residential area but has usually been low. This is a recurrent problem with safety walks (Ceccato \& Hanson, 2013). Ceccato and Hanson suggest that, although safety walks encourage communicative planning, the limited participation of individuals runs the risk of reflecting the views of only a specific group whose voices may be easily heard. If a biased assessment from a safety survey is used as grounds for changes in the built environment, it may unexpectedly help consolidate gender stereotypes - something that goes against the most fundamental goals of the safety survey. Despite potential methodological challenges, safety walks provide valid evidence to be taken into account when the goal is to plan for safe environments.

\section{Final considerations}

What do the Swedish cases tell us about overall violence against women in rural areas? The underreporting of this offense results from the victim's silence, and from the tolerance and inhibition of the social circles surrounding the victims. If rural crime prevention deals with women's safety, it often focuses on perceived safety in outdoor environments. It seems that, so far, interventions against aggression toward women are often guided by the dichotomy of discourse between private versus public spaces that also guide the work done by local CP groups and, to some extent, also the police.

Violence against women is regarded as an important issue by all individuals working in local CP groups who were interviewed. However, these professionals believe that social services or other members of municipal social boards or healthcare experts are the key actors in dealing with domestic violence at the local level. They also highlight the importance of women's shelter organizations (which are rarely found in remote rural areas) and, most importantly, that domestic violence is a question that requires coordinated action among local actors. 
Women's shelter organizations are a cornerstone of efforts to deal with victims of violence in Sweden. However, they are concentrated in urban areas, one-third are in accessible rural municipalities and only three in remote rural municipalities in Sweden. Limited by resources, the type of help they offer varies greatly, from call lines to protection for the victims and housing.

Networking and sharing knowledge are often highlighted as important ingredients in tackling violence in the private sphere when lack of resources is a fact. Our analysis shows that when local partnerships for crime prevention deal with women's safety, the common agenda is to deal with victimization and fear of crime in public spaces (using safety audits or safety walks) and neglects violence in the private sphere. In certain northern rural municipalities, women's violence is regarded as an important issue by CP groups (often associated with alcohol addiction problems). Often however, the priorities of crime prevention are the result of interplay of interests on the part of representatives from the local community, in which the police still play an important role, and may not always focus on violence in the domestic sphere.

Crime prevention groups in northern Sweden differ in terms of organization from those in southern municipalities. All act as crime prevention groups, but northern municipalities clearly have a looser organization, which may not facilitate the challenges they face on a daily basis. Some report problems of dealing with addiction and violence, reaching ethnic minorities that are victims of domestic violence and treating chronic cases as well as problems related to long distances to services and support. They also indicate their own lack of skills and the group's poor resources for tackling violence in the private sphere.

In a more structural account, some claim there is poor support to put into practice national policy guidelines on violence against women, as many problems are multidimensional, touching upon various areas (addiction, unemployment, ethnical minorities, migration laws). This fact reminds us that domestic violence is a product of multi-scale factors and that responses to it should also be multi-scale, requiring better collaboration between national (e.g., Swedish National Council for Crime Prevention - BRÅ), regional (e.g., county), and local scales (e.g., local police force). In the specific case of Sweden, a more accurate inventory of the types of services and support (including financial ones) for women facing violence in the domestic environment in rural areas is necessary. The problems of geographical isolation and remoteness of rural areas, in particular, make public awareness and education campaigns fundamental to transmitting the idea of social responsibility in issues of gendered violence. These changes mean that more resources need to be allocated at different levels, such as healthcare, law enforcement, community services, and support programs for the victims and their children.

Any action ought to be embedded in long-term support for battered women based on the cooperation of local actors at different levels, but some actors believe that the criminal justice system as a whole should play a more central 
role than it does today. For instance, many believe that creating a database of women who repeatedly call for police help in the case of family quarrels will enable police officers who deal with domestic disturbances to follow a more systematic procedure. Of course, the need for local police to be more present and work proactively locally goes against the "centralization winds" that blow in Sweden and characterize the current police reorganization.

Social services also play a role in focusing attention on those who directly experience violence or witness violence against a loved one, such as children and the elderly. In extreme cases, protection of identity and housing are the only solution. Foreign women require special attention, as these women are often highly dependent on the perpetrators, may not be aware of their rights, and have limited language skills. In rural contexts, these barriers can become amplified by geographical and social isolation.

A special group consists of women brought to the country in marriage arrangements. This group of women may need extra support to process events and find a way forward. Women who are not accustomed to living independently or who are new to the country may need support with practical tasks after they have left their partner and are creating a life of their own. A better understanding of the current migration laws is necessary to track cases of violent men who import a "series of wives" from abroad and make use of the current system to send them back as soon as the relationship comes to an end.

Crime prevention of gendered violence has long been based on principles of behavior avoidance, demanding from women the difficult decision to leave their homes to stop violence. Interventions directed at potential perpetrators (men at risk), such as the example from Gotland, can also help prevent violence in a more pro-active way. In the long term, it would be better to have an open discussion of what the current norms of socialization and gender roles are among adults at various levels in society. This is perhaps one of the most important structural challenges in preventing violence. Although violence in the private realm primarily affects women, both men and women are at risk. Knowledge of the extent to which men are exposed to domestic violence is so far insufficient in Sweden. All victims of domestic violence, regardless of gender, gender identity, or gender expression, have a right to assistance and protection.

Information and education programs, especially those directed at young people, improve the odds for change in gender stereotypes and diminish tolerance for gendered violence. The examples discussed here show that there are also initiatives among those dealing with gendered violence in trying to improve their skills and improve the knowledge base to deal with the specific challenges of gendered violence in rural areas. Although many challenges remain untouched, examples of good practices, such as those discussed in this chapter, give hope that change is under way. 


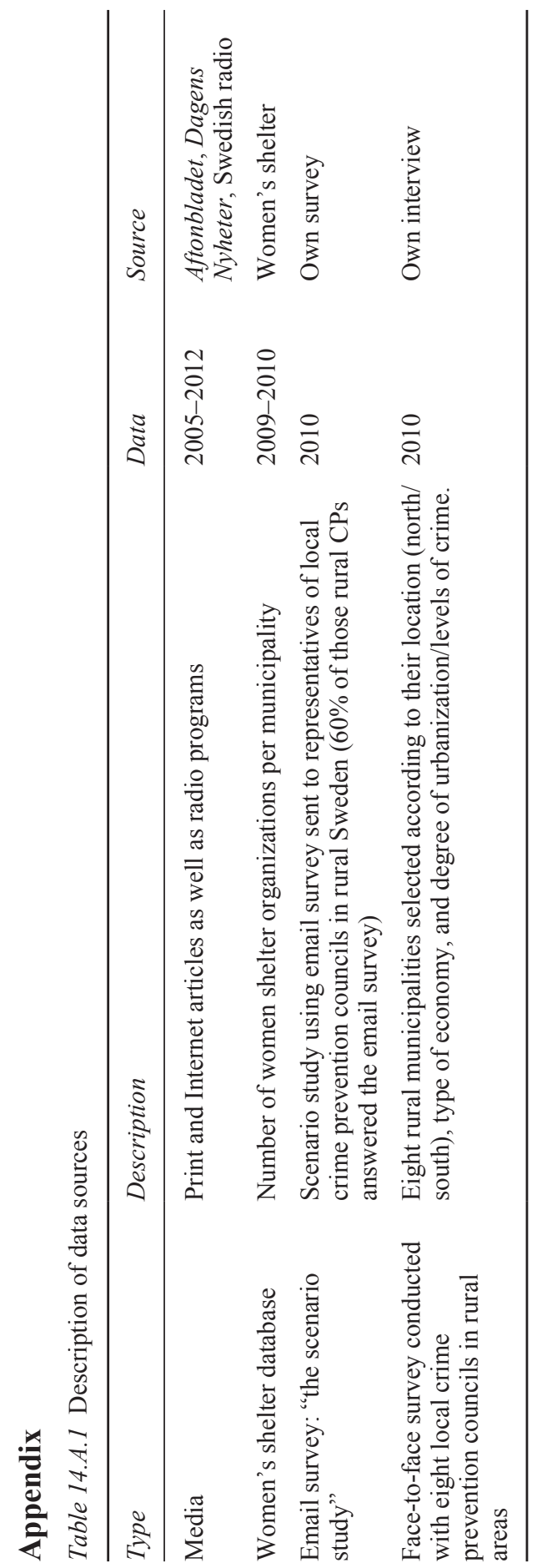




\section{References}

Aguirre, B. E. (1985). Why do they return? Abused wives in shelters. Social Work, 30, $350-354$.

Allen, N. E. N., Bybee, D. I., \& Sullivan, C. M. (2004). Battered women's multitude of needs evidence supporting the need for comprehensive advocacy. Violence Against Women, 10, 1015-1035.

Amcoff, J. (2001). Regionala genuskontrakt i Sverige? Uppsala: Kulturgeografiska institutionen, Uppsala University.

Andréasson, C., Stenson, K., Björck, A., \& Heimer, G. (2006). Den svenska hälso- och sjukvårdens arbete inom kompetensområdet våld mot kvinnor: nationell kartläggning. Uppsala: Rikskvinnocentrum.

Aretun, Å. (2009). Ungdomars utsatthet i bostadsområden: Trygghetsprinciper för fysisk planering. Linköping: Linköping University Electronic Press.

Barclay, E., Donnermeyer, J. F., \& Jobes, P. C. (2004). The dark side of gemeinschaft: Criminality within rural communities. Crime Prevention and Community Safety, 6(3), 7-22.

Beausang, A. (2012). Satsning mot kvinnovåld resultatlös. Dagens Nyheter. Retrieved April 17, 2015, from www.dn.se/nyheter/sverige/satsning-mot-kvinnovald-resultatlos/.

Bennett, L., \& Williams, O. (2001). Controversies and recent studies of batterer intervention program effectiveness. Harrisburg, PA: National Electronic Network on Violence Against Women. Retrieved April 17, 2015, from www.vawnet.org/applied-researchpapers/print-document.php?doc_id=373.

Benson, S. R. (2009). Failure to arrest: A pilot study of police response to domestic violence in rural Illinois. American University Journal of Gender, Social Policy and the Law, 17, 685-703.

Brottsförebyggande rådet - BRÅ (National Council of Crime Prevention). (2008). Nationella trygghetsundersökningen 2007: Om utsatthet, trygghet och förtroende. Stockholm: BRÅ.

Brottsförebyggande rådet - BRÅ (2009). Våld mot kvinnor och män i nära relationer (Vol. 12). Stockholm: BRÅ.

Bull, M. (2007). Alcohol and drug problems in rural and regional Australia. In J. F. D. E. Barclay, J. Scott, \& R. Hogg (Eds.), Crime in rural Australia (pp. 71-85). Sydney: Federation Press.

Carrington, K. (2007). Crime in rural and regional areas. In J. F. D. E. Barclay, J. Scott, \& R. Hogg (Eds.), Crime in rural Australia (pp. 27-43). Sydney: Federation Press.

Ceccato, V., \& Dolmén, L. (2013). Crime prevention in rural Sweden. European Journal of Criminology, 10, 89-112.

Ceccato, V., \& Hanson, M. (2013). Experiences from assessing safety in Vingis Park, Vilnius, Lithuania. Review of European Studies, 5(5), 1-16.

Coker, D. (2004). Race, poverty, and the crime-centered response to domestic violence: A comment on Linda Mills's insult to injury: rethinking our responses to intimate abuse. Violence Against Women, 10, 1331-1353.

Danis, F. S. (2003). The criminalization of domestic violence: What social workers need to know. Social Work, 48, 237-246.

DeKeseredy, W. S., Donnermeyer, J. F., \& Schwartz, M. D. (2009). Toward a gendered second generation CPTED for preventing woman abuse in rural communities. Security Journal, 22, 178-189.

DeKeseredy, W. S., Schwartz, M. D., \& Alvi, S. (2008). Which women are more likely to be abused? Public housing, cohabitation, and separated/divorced women. Criminal Justice Studies, 21(4), 283-293. 


\section{Sweden: policing and crime prevention}

Donnermeyer, J. F., Plested, B. A., Edwards, R. W., Oetting, G., \& Littlethunder, L. (1997). Community readiness and prevention programs. Journal of the Community Development Society, 28(1), 65-83.

Eriksson, M. (2011). Contact, shared parenting, and violence: Children as witnesses of domestic violence in Sweden. International Journal of Law, Policy and the Family, 25(2), 165-183.

Ferraro, K. F. (1995). Fear of crime: Interpreting victimization risk. Albany, NY: State University of New York Press.

Home Office. (1994). Preventing domestic violence to women (R. M. Morley \& A. Mullender, Eds.). London: Home Office.

Hoyle, C. (2008). Will she be safe? A critical analysis of risk assessment in domestic violence cases. Children and Youth Services Review, 30, 323-337.

Ingesson, M. (2012). Mer kunskap om samiska kvinnor: Viktigt för kvinnojouren i Storuman. Retrieved April 17, 2015, from http://sverigesradio.se/sida/artikel.aspx?programi $\mathrm{d}=2327 \&$ artikel $=983273$.

Jönsson, B. (2013, November 8). Kvinnomord hade kunnat hindras. Sveriges Radio (Producer). Retrieved from http://sverigesradio.se/sida/artikel.aspx?programid=104\&artikel $=5698685$.

Lagrange, R. L., \& Ferraro, K. F. (1989). Assessing age and gender diferences in perceived risk and fear of crime. Criminology, 27(4), 697-720.

Loukaitou-Sideris, A. (2014). Fear and safety in transit environments from the women's perspective. Security Journal, 27, 242-256.

Lovett, J., \& Kelly, L. (2009). Different systems, similar outcomes? Tracking attrition in reported rape cases across Europe. London: Child and Woman Abuse Studies Unit.

Mills, L. G. (1998). The heart of intimate abuse: New interventions in child welfare, criminal justice, and health settings. New York: Springer.

Nationellt centrum för kvinnofrid - NCK. (2001). Kommunerna som blunder för mäns våld mot kvinnor (p. 28). Stockholm: National Council for Women’s Freedom (NCK), Victim Support Association.

Owen, S., \& Carrington, K. Domestic violence (DV) service provision and the architecture of rural life: An Australian case study. Journal of Rural Studies(0). doi: http://dx. doi.org/10.1016/j.jrurstud.2014.11.004

Pruitt, L. R. (2008). Place matters: Domestic violence and rural difference. Wisconsin Journal of Law, Gender and Society, 32, 346-416.

Rying, M. (2012, June 3). Satsning mot kvinnovåld resultatlös. Dagens Nyheter. Retrieved April 17, 2015, from www.dn.se/nyheter/sverige/satsning-mot-kvinnovald-resultatlos/.

Sandberg, K. (2010). Ett tryggare Gotland: En studie om trygghetsarbete i den offentliga miljön. Arbetsrapporter. Uppsala: Department of Human Geography, Uppsala University.

Saville, G., \& Clear, T. (2000). Community renaissance with community justice. Neighborworks Journal, 18, 18-24.

Stengård, M. (2009, December 5). Färre åtal för kvinnovåld. Aftonbladet.

Stover, C. S. (2005). Domestic violence research: What have we learned and where do we go from here? Journal of Interpersonal Violence, 20, 448-454.

Sullivan, C. M., \& Bybee, D. I. (1999). Reducing violence using community-based advocacy for women with abusive partners. Journal of Consulting and Clinical Psychology, $67,43-53$.

Sullivan, C. M., \& Gillum, T. (2001). Shelters and community based services for battered women and their children. In J. L. E. C. M. Renzetti \& R. Bergen (Eds.), Sourcebook on violence against women (pp. 247-260). Thousand Oaks, CA: Sage. 
Swedish Association of Local Authorities and Regions - SKL. (2009). Utveckling pågår En kartläggning av kvinnofridsarbetet i kommuner, landsting och regioner. Stockholm: SKL.

Tolman, R. M., \& Edleson, J. L. (1995). Intervention for men who batter: A review of research. In S. R. S. M. A. Straus (Ed.), Understanding partner violence: Prevalence, causes, consequences and solutions (pp. 262-273). Minneapolis, MN: National Council on Family Relations.

Townsend, J. G. (1991). Towards a regional geography of gender. Geographical Journal, $157,25-35$.

United Nations - UN. (2011). What is a coordinated community response to violence against women? The United Nations for gender equality and the empowerment of women. Retrieved April 17, 2015, from www.endvawnow.org/en/articles/127-what-isa-coordinated-community-response-to-violence-against-women.html.

Women's Action Centre against Violence Ottawa-Carleton - WACAV. (1995). Safety audit tools and housing: The state of the art and implications for CMHC. Ottawa, Canada: Canada Mortgage and Housing Association, Victim Support.

Weinehall, K. (2005). Mäns våld mot kvinnor i nära relationer Polisens hantering av en brottslig handling (p. 85). Umeå: Umeå universitet, Pedagogiska institutionen.

Weinehall, K. (2006). Räkna med kostnader: en fallstudie om mäns våld mot kvinnor. Paper presented at the Brottsoffermyndighetens konferens på Internationella brottsofferdagen, Stockolm. Retrieved April 17, 2015, from http://urn.kb.se/resolve?urn=urn:nbn:se:umu: diva-32094.

Weinehall, K. (2011). Mäns våld mot kvinnor i nära relationer Polisens hantering av en brottslig handling. Umeå: Umeå universitet, Pedagogiska institutionen.

Socialstyrelsen (National Board of Health and Welfare). (2013). Skyddat boende: en jämförelse med Danmark och Norge. Stockholm: Socialstyrelsen.

Socialstyrelsen (National Board of Health and Welfare). (2014). Ensam och utsatt: Utbildningsmaterial om våld mot kvinnor med utländsk bakgrund (p. 60). Stockholm: Socialstyrelsen.

Svenska kvinnorörelsen - SKR. (2009). Women's shelters by Swedish municipalities [Database]. Stockholm: National Organisation for Women's Shelters and Young Women's Shelters (ROKS).

Westman, M. (2010). Women of Thailand (Master's thesis, University of Linköping, Linköping). 